American Journal of Agricultural and Biological Sciences 6 (1): 12-18, 2011

ISSN 1557-4989

C 2010 Science Publications

\title{
The Reproductive Tract of the Males of the Zoophytophagous Predator Brontocoris tabidus (Signoret) (Heteroptera: Pentatomidae) with Different Diets and Ages
}

\author{
${ }^{1}$ Walkymario de Paulo Lemos, ${ }^{2}$ Rafael Coelho Ribeiro, ${ }^{3}$ Francisco de Sousa Ramalho, \\ ${ }^{4}$ Jose Eduardo Serrao and ${ }^{2}$ Jose Cola Zanuncio \\ ${ }^{1}$ Laboratory of Entomology, Embrapa-Oriental Amazonian, Belem, Para, Brazil \\ ${ }^{2}$ Department of Animal Biology, Federal University of Viçosa, Viçosa, Minas Gerais, Brazil \\ ${ }^{3}$ Biological Control Unity, Embrapa-cottonCampina Grande, Paraíba, Brazil \\ ${ }^{4}$ Department of General Biology, Federal University of Viçosa, Viçosa, Minas Gerais, Brazil
}

\begin{abstract}
Problem statement: Brontocoris tabidus (Signoret) (Heteroptera: Pentatomidae) is a common and important species for the biological control of defoliating Lepidoptera caterpillars. Although it has a predatory feeding habit, this species make use of plant resources, which are essential for the maintenance of its population in laboratory colonies as well as in the field during periods of prey shortage. Thus $B$. tabidus has been considered an obligate zoophytophagous insect. However the impact of the age and herbivory on the morphology of the reproductive organs has been poorly studied in predatory Pentatomidae. The morphology of the reproductive tract of $B$. tabidus males with different ages and fed on different diets were analyzed. Approach: Nymphs of B. tabidus were maintained in the field with or without plants and fed on T. molitor pupae without plant $\left(\mathrm{T}_{1}\right) ;$ T. molitor pupae and Eucalyptus cloeziana plants $\left(\mathrm{T}_{2}\right) ;$ T. molitor pupae and Eucalyptus urophylla plants $\left(\mathrm{T}_{3}\right)$ or T. molitor pupae and guava plants (Psidium guajava $\mathrm{L}$.) $\left(\mathrm{T}_{4}\right)$. Adults of $B$. tabidus obtained from each treatment were sexed in the first day of their emergence and thirty-six pairs were formed per treatment. Ten males of B. tabidus 15 and 21 days old, obtained in each treatment were dissected and the reproductive tract submitted to histological analyses. The total area of the testes of B. tabidus was measured and the data were submitted to the variance analysis and means between treatments were compared by the test of Newman-Keuls $(\mathrm{p}=0.05)$. Results: The inner genitalia of B. tabidus males had red color and the testes with six follicles. Males 15 days old presented larger testes when fed on E. cloeziana $\left(0.94 \mathrm{~mm}^{2}\right)$, E. urophylla $\left(0.98 \mathrm{~mm}^{2}\right)$ or only $T$. molitor pupae $\left(0.99 \mathrm{~mm}^{2}\right)$ than with guava plants $\left(0.76 \mathrm{~mm}^{2}\right)$. Twenty-one days old B. tabidus males presented testes with similar size, independent of the diet. The testes follicles of $B$. tabidus had larger amount of spermatozoa with all diets and ages showing that the spermatogenesis process was completed. The testes of this predator showed similar histological characteristics with all diets. Conclusion: The herbivory change the morphology of the reproductive tract of $B$. tabidus males in field conditions resulting in testes with different sizes, but it does not affect the histology of the reproductive organ of this predator. Therefore, the food type supplied to $B$. tabidus males does not affect the spermatogenesis process in this natural enemy.
\end{abstract}

Key words: Brontocoris tabidus, spermatocytes, Tenebrio molitor, Podisus nigrispinus, Troilus luridus, zoophytophagous, heteroptera, Federal University of Viçosa (UFV), pentatomidae, asopinae, phytophagy, Perillus bioculatus, reproduction, Supputius cincticeps, testis, Eucalyptus cloeziana, morphology, Eucalyptus urophylla

\section{INTRODUCTION}

Asopinae predators has been used in Integrated Pest Management programs specially Podisus maculiventris (Say) and Perillus bioculatus (F.) (Heteroptera: Pentatomidae) in North America and
Europe (Adams, 2000). Podisus nigrispinus (Dallas), Brontocoris tabidus (Signoret) and Supputius cincticeps (Stäl) (Heteroptera: Pentatomidae) in South America (Zanuncio et al., 2000; 2004; Lemos et al., 2003; 2005a; 2005b), Eocanthecona furcellata (Wolff) (Heteroptera: Pentatomidae) in the Southeast Asia and

Corresponding Author: Department of General Biology, Federal University of Viçosa, 36570-000, Viçosa, Minas Gerais, Brazil Tel: +55 31 38991301. Fax: +55 3138992549 
India (De Clerq, 2000), Troilus luridus F. and Zicrona caerulea L in European Russia (Shestakov, 2008) and Picromerus bidens (Linnaeus) distributed in the western Palearctic region (Mahdian et al., 2008).

Brontocoris tabidus is a common and important species in Brazil for the biological control of defoliating Lepidoptera caterpillars (Zanuncio and Fabres, 2001; Zanuncio et al., 2006; Oliveira et al., 2005) in forest which a pests (Zanuncio et al., 1996; Zanuncio and Fabres, 2001) and agricultural systems. Eggs, immature and adults of this natural enemy are, frequently, found in plantations of Eucalyptus cloeziana and Eucalyptus urophylla, mainly, in outbreaks of defoliator caterpillars (Jusselino-Filho et al., 2003; Zanuncio et al., 2006), what shows its potential for programs of integrated pest management Zanuncio et al., 2006).

The use of plants as a food complement for predatory Pentatomidae has been studied, especially, to explain its effects on the survival and longevity of these natural enemies (Armer et al., 1998). The use of vegetable material seems to supply essential nutrients or amino acids not found in the prey (Eubanks and Denno, 1999) with positive effects on the biological aspects of these organisms (Bilde and Toft, 1994; Toft, 1995; Coll and Izraylevich, 1997; Armer et al., 1998; Coll and Guershon, 2002). Besides, omnivorous insects feeding on prey and plant can have better use of the food (Coll and Guershon, 2002).

Zoophytophagous predators feed on prey and/or on plants (Agrawal et al., 1999; Eubanks and Denno; 1999; Coll and Guershon, 2002; Azevedo et al., 2007; Guedes et al., 2007) with benefits for biological control of insect pests by improving the maintenance of the populations of these natural enemies during periods of prey shortage (Cocuzza et al., 1997). However, the morphological features of the reproductive organs and the fecundity of predatory Pentatomidae can be affected by factors such as unfavorable environmental conditions and quantity or quality of the food (Lemos et al., 2005a; 2005b).

Pentatomidae are important for the biological control but the internal morphology of the reproductive organs of these natural enemies, especially of their males have been poorly studied, except for $P$. nigrispinus (Lemos et al., 2005b). Besides, the internal reproductive organs of Pentatomidae are used as taxonomic characters (Ahmad and McPherson, 1998).

The objective of this work was to evaluate the impact of different diets in the field on the morphology of the fat body and of the reproductive tract of males of the predator $B$. tabidus with two ages.

\section{MATERIALS AND METHODS}

The research was carried out in the field in an area of the Department of Animal Biology and in the laboratories of Biological Control of Insects of the Institute of Applied Biotechnology to Agriculture (BIOAGRO) and in the laboratories of Molecular and Cell Biology and Reproductive Histology of the Department of General Biology of the Federal University of Vicosa (UFV) in Vicosa, State of Minas Gerais, Brazil.

Specimens of $B$. tabidus were obtained from colonies maintained in the laboratory of Biological Control of Insects and of the UFV where this predator is reared in wood screened cages $(30 \times 30 \times 30 \mathrm{~cm})$ with a glass container with water and Eucalyptus urophylla leaves as vegetable substratum for feeding. Tenebrio molitor L. (Coleoptera: Tenebrionidae) pupae were supplied from the mass rearing facility of the Laboratory of Biological Control of Insects of the UFV for B. tabidus in the upper part of the cages.

Twenty couples of $B$. tabidus were used per treatment with newly emerged adults in the laboratory to obtain the progeny used in the research. Nymphs and adults of $B$. tabidus were maintained in the field with or without plants in bags of tissue type organza $(70 \times 40$ $\mathrm{cm}$ ) (Zanuncio et al., 2004) and fed on T. molitor pupae without plant $\left(\mathrm{T}_{1}\right) ; T$. molitor pupae and Eucalyptus cloeziana plants $\left(\mathrm{T}_{2}\right) ;$ T. molitor pupae and Eucalyptus urophylla plants $\left(\mathrm{T}_{3}\right)$ or $T$. molitor pupae and guava plants (Psidium guajava $\mathrm{L}$.) $\left(\mathrm{T}_{4}\right)$.

Five hundred nymphs of $B$. tabidus were used in each diet treatment. These nymphs were obtained from the twenty pairs of the laboratory and they were put in organza bags up to the adult stage. T. molitor pupae were supplied ad libitum and changed with the water twice a week. Nine hundred individuals were used in the $\mathrm{T}_{1}$ due to the high mortality of nymphs of B. tabidus in this treatment.

The adults of $B$. tabidus were sexed in the first day of their emergency based on the external appearance of the genitally and mated. Thirty-six pairs were formed per treatment. The $\mathrm{T}_{1}$ had 50 pairs due to a higher mortality in this treatment. B. tabidus adults received the same prey type and/or plants of the nymphs that originated them. The pairs of this predator were maintained in organza bags $(25 \times 15 \mathrm{~cm})$ involving branches of plants with water in $2.5 \mathrm{~mL}$ plastic tubes (Zanuncio et al., 2004). T. molitor pupae were supplied ad lib. and changed twice a week with the water. The organza bags of the $T_{1}$ were maintained in the plants but not involving their branches. Males of the same treatment substituted those that died before their respective females. The pair was substituted if the female died before the evaluation date and the number of dead individuals was registered every $48 \mathrm{~h}$. 
Ten males of B. tabidus 15 and 21 days old, obtained in each treatment were transferred to Zamboni fixative solution (Stefanini et al., 1967). The reproductive tract of $B$. tabidus was removed with the aid of surgical scissors. The samples were dehydrated in graded ethanol series and embedded in historesina JB-4. Sections $5 \mu \mathrm{m}$ thin were stained with hematoxyline and eosin analyzed and photographed under photomicroscope.

The total area of the testes of B. tabidus was quantified with aid of the computer program Image ProPlus, version 4.5.1.29 (Media Cybernetics), for 15 and 21 days old males per diet.

The area of the testes of B. tabidus was submitted to the variance analysis and means between treatments were compared by the test of Newman-Keuls $(\mathrm{p}=0.05)$.

\section{RESULTS}

The inner genitalia of $B$. tabidus males are found in the abdominal cavity of the body of this predator immediately below its alimentary canal. It extends from the genital capsule to the end of the thorax and it is involved by the fat body. The reproductive tract is formed by a pair of testes, two vasa deferetia that join to form the ejaculatory duct and the aedeagus (Fig. 1A). The testes are placed in the distal area of the abdomen of B. tabidus and they present an intense red color and compact structures with round or lightly prolonged shaped (Fig. 1B). The testis follicles of B. tabidus present a compact structure and they are only differentiated by histological studies. The vas deferens present also an intense red color and an aspect of long filaments joined to the ejaculatory duct, which is yellowish and the copulatory organ of $B$. tabidus males presents an esclerotized aspect (Fig. 1A). Opening into the ejaculatory duct there are five pairs of accessory glands.

The area of the testes of mated males of B. tabidus was affected by the interaction diet $\mathrm{x}$ age of this predator $(\mathrm{F}=6.89$; $\mathrm{df}=3,152 ; \mathrm{p}<0.01)$. Fifteen days old males of this predator presented larger testes when fed on E. cloeziana $\left(0.94 \pm 0.04 \mathrm{~mm}^{2}\right)$, E. urophylla $\left(0.98 \pm 0.03 \mathrm{~mm}^{2}\right)$ or $T$. molitor pupae alone $(0.99 \pm$ $\left.0.04 \mathrm{~mm}^{2}\right)$ than with guava plants $\left(0.76 \pm 0.03 \mathrm{~mm}^{2}\right)$ (Fig. 2). However, 21 days old B. tabidus males have testes with similar size in all diets (Fig. 2). The area of the testes of $B$. tabidus was larger for those individuals 15 days old than with 21 days in all diets except with guava plants. The testis area of 21 days old males ( 0.86 $\pm 0.03 \mathrm{~mm}^{2}$ ) was larger with this plant than for those 15 days old $\left(0.76 \pm 0.03 \mathrm{~mm}^{2}\right)$ (Fig. 2).

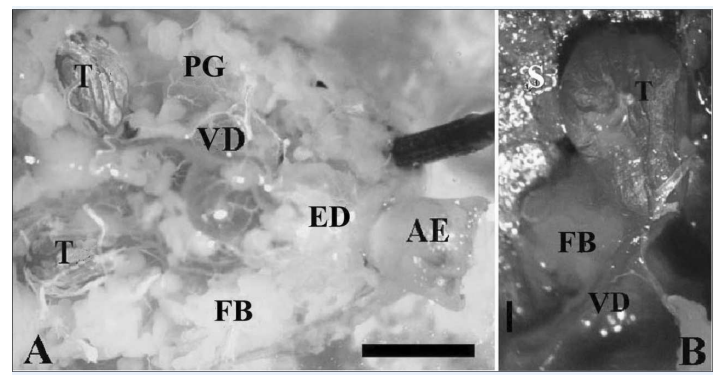

Fig. 1: General view of the reproductive tract (A) and detailed aspect of the testis of mated male of Brontocoris tabidus (Heteroptera: Pentatomidae) (B). AE, aedeagus; ED, ejaculatory duct; FB, fat body; PG, pheromone gland; S, sternite; T, testis; VD, vas deferens. Bars $=1.5 \mathrm{~mm}(\mathrm{~A})$ and $0.17 \mathrm{~mm}(\mathrm{~B})$

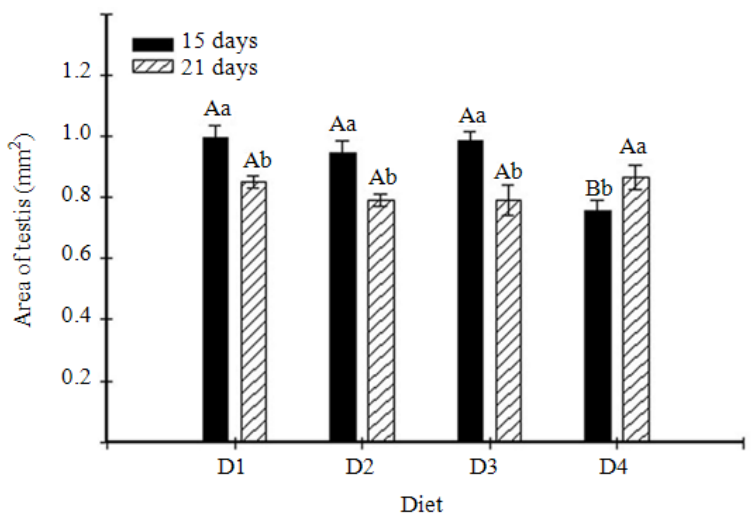

Fig. 2: Size of the testes (mean \pm standard error) of Brontocoris tabidus (Heteroptera: Pentatomidae) males with 15 or 21 days old in the field fed on different diets. Columns followed by the same small letter per age or capital letter per diet do not differ between them by the Newman-Keuls test $(\mathrm{p}=0.05)$

Brontocoris tabidus has testes with six follicles independent of the diet and age. These follicles present a germarium in the distal portion (Fig. 3C, 3D) lined by a layer of cells forming the follicular sheath, resulting in a testis strongly compacted (Figs. 3A, 3B). The follicular sheath of $B$. tabidus presented several layers composed by flattened cells with flat nucleus containing condensed chromatin (Fig. 3D, 4A).

The spermatocytes inside the follicles of $B$. tabidus are clearly isolated in cysts (Fig. 3C, 3D). Cells in process of synchronized division (area I) were observed inside the cysts in all diets and ages of this predator (Fig. 3C, 4B). All cysts showed similar growing along the follicles towards the area of the vas deferens. 

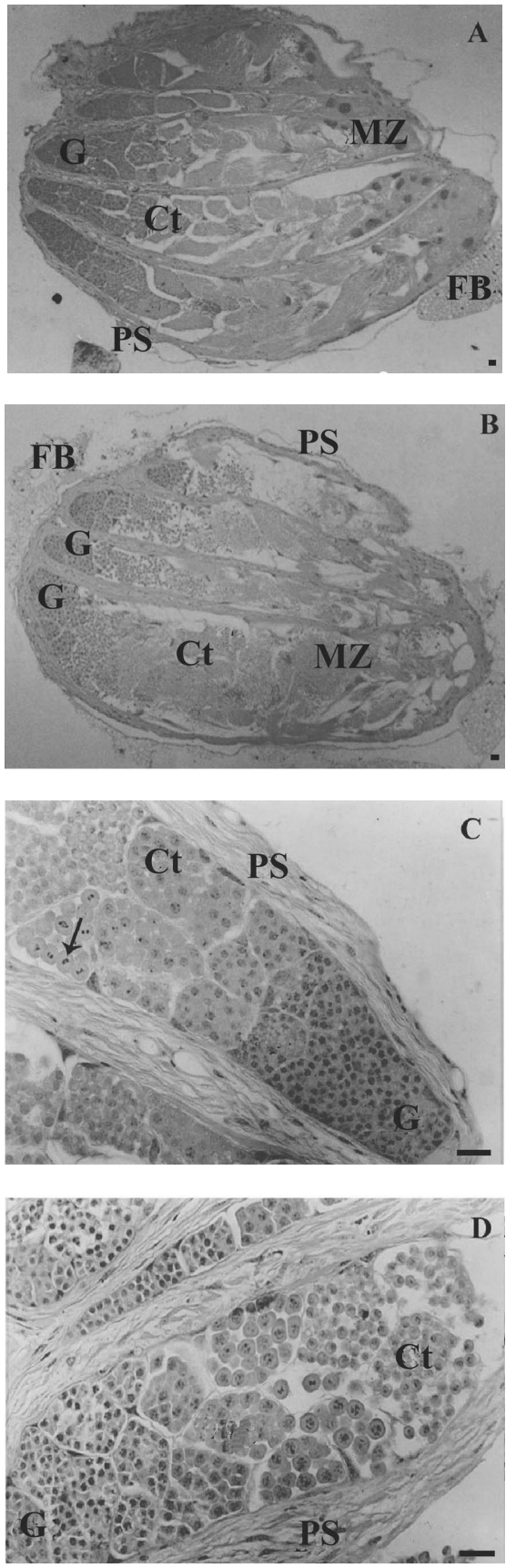

Fig. 3: Longitudinal section of the testis of Brontocoris tabidus (Heteroptera: Pentatomidae) fed on different diets. Note differences in the thickness of the follicles of 15 days old males fed on Tenebrio molitor pupae (A) or pupae of this prey and guava plant (B). Detail of the testis follicle (C, D). Arrow-cells in division; FB-fat body; Ggermarium region; Ct-cyst; PS-follicular sheath; MZ- maturation zone II. Bars $=20 \mu \mathrm{m}$
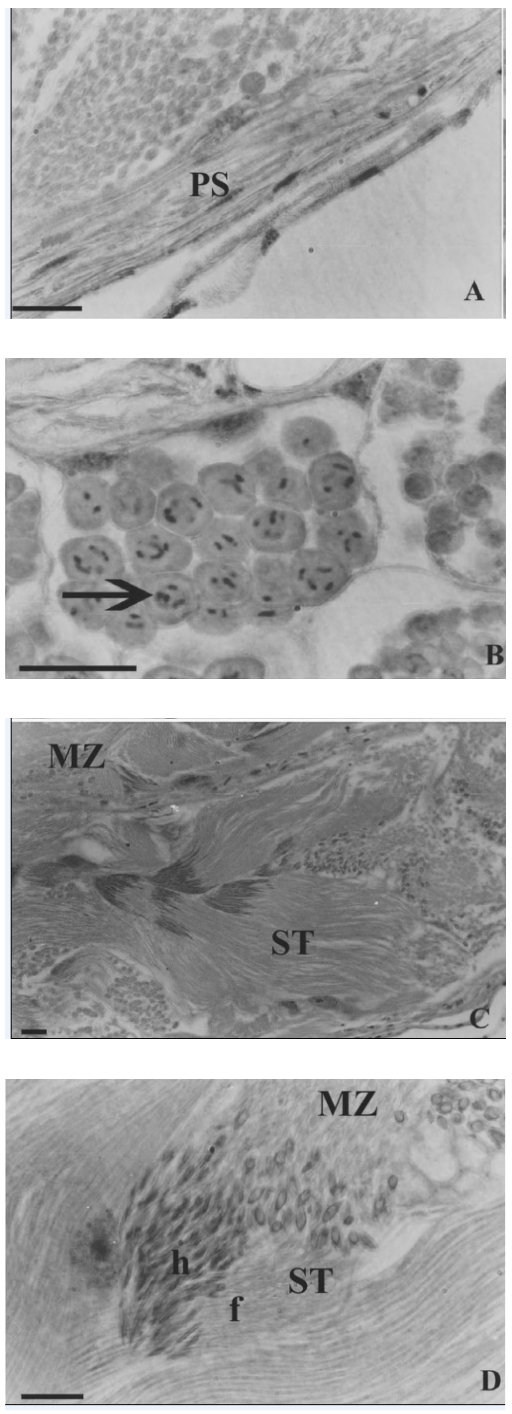

Fig. 4: Longitudinal section of the testes of Brontocoris tabidus (Heteroptera: Pentatomidae) fed on different diets. (A) Follicular sheath (PS). (B) Cells in division in the interior of the cyst (arrow). C, (D) Maturation zone showing the spermatids (ST) inside the follicles with elongated head (h) and the flagellum (f). Bars $=20 \mu \mathrm{m}$

Mature spermatocytes of B. tabidus were found in the maturation area (area II) (Fig. 4C, 4D). Spermatocytes were observed inside the follicles of $B$. tabidus in different development stages. Also the spermatids at different developmental stages were observed in the transformation area (area III) arisen the spermatozoa, which were released in cluster inside the vas deferens. Brontocoris tabidus had high amount of spermatozoa in all diets and ages near the vas deferens. 
The histological features of $B$. tabidus was not affected by the diet and age.

\section{DISCUSSION}

The inner genitalia of B. tabidus males is similar to that of other Heteroptera predators (Lemos et al., 2005b). Its intense red color seems to be a peculiar morphological feature of many species of this group of predators (Lemos et al., 2005b). Males of Podisus nigrispinus (Dallas) (Heteroptera: Pentatomidae) presented testes with intense red coloration (Lemos et al., 2005b). Studies on the morphology and histology of the inner genitalia of Heteroptera predators males are recent and scarce mainly the effect of the food on these structures. However, the reproductive tracts of $B$. tabidus males present general aspect similar to those of other insects (Lemos et al., 2005b; Ortiz and CamargoMathias, 2006; Roma et al., 2006).

Fifteen days old males of B. tabidus presented smaller testes when fed on guava plants. The development of the follicles and the production of reproductive (cysts) cells were higher in the testes of this predator fed on E. cloeziana, E. urophylla or, only, T. molitor pupae. However the testes of 21 days old males of B. tabidus presented similar size and high production of reproductive cells in all diets including guava plants. This suggests that the size of the testes does not affect the reproductive capacity of $B$. tabidus with high production of spermatozoa in all diets. Besides, the energy and the nutrients resources necessary for the production of germ cells are lower than that for the production of eggs (Wheeler, 1996). This can indicate a low impact of the diet type on the germ cell production or on the reproductive success of B. tabidus males. Podisus maculiventris presented lower production of spermatozoa when fed on artificial diet (Zanuncio et al., 2004). This corroborates the hypothesis that the nutrition of Heteroptera females is more important for the reproductive success of these natural enemies, but the role of the Pentatomidae males in the reproductive physiology of their females needs to be better studied ((Lemos et al., 2005b).

Histological studies of the male reproductive tract showed that the diet type did not affect the histological characteristics of the testes of B. tabidus. However, the testes of $P$. nigrispinus presented an accentuated degree of cell death when fed on artificial diet what demonstrates a negative effect of this food on the reproductive potential of this predator (Lemos et al., 2005b).
Males of B. tabidus presented six follicles per testis in all diets and ages. The number of follicles per testis of Heteroptera varies from six for P. nigrispinu to seven for $P$. bioculatus (Lemos et al., 2005b). Although this author suggested that this last number should be typical for Pentatomidae this was not observed for B. tabidus. This indicates that the number of follicles per testis of Pentatomidae predators can be species-specific (Lemos et al., 2005b) such as observed for the ovariole number of females of these predators (Buning, 1994).

Cells in differentiation process were observed inside the follicles for all diets and age of B. tabidus males what shows that they were active and producing a great quantity of spermatozoa.

\section{CONCLUSION}

The herbivory change the morphology of the reproductive tract of $B$. tabidus males in field conditions resulting in testes with different sizes, but it does not affect the histology of the reproductive organ of this predator. Therefore, the food type supplied to $B$. tabidus males does not affect the spermatogenesis process in this natural enemy. These results may increase the chances of success in biological control programs of pests and the knowledge on the nutritional and hormonal requirements of males of the predator $B$. tabidus reared in the field.

\section{ACKNOWLEDGEMENT}

To the Brazilian research agencies "National Council for Scientific and Technological Development" (CNPq) and "Minas Gerais State Research Agency" (FAPEMIG).

\section{REFERENCES}

Adams, T.S., 2000. Effect of diet and mating status on ovarian development in a predaceous stink bug Perillus bioculatus (Hemiptera: Pentatomidae). Ann. Entomol. Soc. Am., 93: 529-535. 529-535. DOI: $10.1603 / 0013-$ 8746(2000)093[0529:EODAMS]2.0.CO;2

Agrawal, A.A., C. Kobayashi and J.S. Thaler, 1999. Influence of prey availability and induced hostplant resistance on omnivory by western flower thrips. Ecol., 80: 518-523. DOI: 10.1890/00129658(1999)080[0518:IOPAAI]2.0.CO;2

Ahmad. I. and J.E. McPherson, 1998. Additional information on male and female genitalia of Parabrochymena lariviere and Brochymena amyot and serville (Hemiptera: Pentatomidae). Ann. Entomol. Soc. Am., 91: 800-807. DOI: 10.1603/00138746(2007)100[673:ROBAPH]2.0.CO;2 
Armer, C.A., R.T.N. Wiedenmann and D.R. Bush, 1998. Plant feeding site selection on soybean by the facultatively phytophagous predator Orius insidiosus. Entomol. Exp. Appl., 86: 109-118. DOI: 10.1046/j.1570-7458.1998.00271.x

Azevedo, D.O., J.C., Zanuncio, J.S., Zanuncio Jr., G.F. Martins and S. Marques-Silva et al., 2007. Biochemical and morphological aspects of salivary glands of the predator Brontocoris tabidus (Heteroptera: Pentatomidae). Braz. Arch. Biol. Techn., 50: 469-477. DOI: 10.1590/S151689132007000300013

Bilde, T and S. Toft, 1994. Prey preference and egg production of the carabid beetle Agonum dorsale. Entomol. Exp. Appl., 73: 151-156. DOI: 10.1007/BF02383421

Buning, J., 1994. The Ovary of Ectognatha. In: The Insect Ovary-Ultrastructure, Previtellogenic Growth and Evolution, Bunning, J. (Ed.). Chapman and Hall, ISBN: 0412360802, pp: 31-324.

Cocuzza, G.E., P. De Clercq, M. Van de Veire, A. Cock and D. Degheele et al., 1997. Reproduction of Orius laevigatus and Orius albidipennis on pollen and Ephestia kuehniella eggs. Entomol. Exp. Appl. 82: $\quad 101-104$. DOI: $10.1046 / \mathrm{j} .1570-$ 7458.1997.00118.x

Coll, M. and M. Guershon, 2002. Omnivory in terrestrial arthropods: Mixing plant and prey diets. Ann. Rev. Entomol. 47: 267-297. DOI: 10.1146/annurev.ento.47.091201.145209

Coll, M. and S. Izraylevich, 1997. When predators also feed on plants: effects of competition and plant quality on omnivore-prey population dynamics. Ann. Entomol. Soc. Am., 90: 155-161. http://www.entsoc.org/pubs/periodicals/ann/ANNT OCS/all_ann_tocs.htm\#Mar1997

De Clercq, P., 2000. Predaceous Stinkbugs (Pentatomidae: Asopinae). In: Heteroptera of Economic Importance, Schaefer, C.W. and A.R. Panizzi (Eds.). Cambridge University Press, ISBN: 0849306957, pp: 737-789.

Eubanks, M and R.F. Denno, 1999. The ecological consequences of variation in plants and prey for an omnivorous insect. Ecology, 80: 1253-1266. DOI: $10.1890 / 0012-$ 9658(1999)080[1253:TECOVI]2.0.CO;2

Guedes, B.A.M., J.C. Zanuncio, F.S. Ramalho and J.E. Serrao, 2007. Midgut morphology and enzymes of the obligate zoophytophagous stinkbug Brontocoris tabidus (Signoret, 1863) (Heteroptera: Pentatomidae). Pan-Pac. Entomol., 83: 66-74. DOI: 10.3956/0031-0603-83.1.66
Jusselino Filho, P, J.C. Zanuncio, D.B. Fragoso, J.E. Serrao and M.C. Lacerda, 2003. Biology of Brontocoris tabidus (Heteroptera: Pentatomidae) fed with Musca domestica (Diptera: Muscidae) larvae. Braz. J. Biol., 63: 463-468. DOI: 10.1590/S151969842003000300012

Lemos, W.P., R.S. Medeiros, F.S. Ramalho and J.C. Zanuncio, 2001. Effects of plant feeding on the development, survival and reproduction of Podisus nigrispinus (Dallas) (Heteroptera: Pentatomidae). Inter. J. Pest Manage., 47: 89-93. DOI: 10.1080/09670870151130499

Lemos, W.P., F.S. Ramalho, J.E. Serrao and JC. Zanuncio, 2003. Effects of diet on development of Podisus nigrispinus (Dallas) (Het., Pentatomidae), a predator of the cotton leafworm. J. Applied Entomol., 127: 389-395. DOI: 10.1046/j.14390418.2003.00765.x

Lemos, W.P., F.S. Ramalho, J.E. Serrao and J.C. Zanuncio, 2005a. Morphology of female reproductive tract of the predator Podisus nigrispinus (Dallas) (Heteroptera: Pentatomidae) fed on different diets. Braz. Arch. Biol. Techn., 48: $\quad 129-138$. DOI: $10.1590 / \mathrm{S} 1516-$ 89132005000100017

Lemos, W.P., J.E. Serrao, F.S. Ramalho and J.C. Zanuncio, 2005b. Effect of diet on male reproductive tract of Podisus nigrispinus (Dallas) (Heteroptera: Pentatomidae). Braz. J. Biol., 65: 16. DOI: $10.1590 / \mathrm{S} 1519-69842005000100012$

Mahdian, K., T. Luc and P. De Clercq, 2008. Development of the predatory pentatomid Picromerus bidens (L.) at various constant temperatures. Belg. J. Zool., 138: 135-139. http://www.naturalsciences.be/institute/association s/rbzs_website/bjz/back/pdf/BJZ\%20138(2)/Volum e\%20138(2),\%20pp.\%20135-139.pdf.

Medeiros, R.S., F.S. Ramalho, J.E. Serrao and J.C. Zanuncio, 2004. Estimative of Podisus nigrispinus (Dallas) (Heteroptera: Pentatomidae) development time with non linear models. Neotrop. Entomol., 33: $141-148 . \quad$ DOI: $10.1590 / \mathrm{S} 1519-$ 566X2004000200003

Oliveira, I., J.C. Zanuncio, J.E. Serrao, T.V. Zanuncio, T.B.M. Pinon and M.C.Q. Fialho, 2005. Effect of female weigth on reproductive potential of the predator Brontocoris tabidus (Signoret, 1858) (Heteroptera: Pentatomidae). Braz. Arch. Biol. Techn., 48: 295-301. DOI: 10.1590/S151689132005000200017

Ortiz, G. and M.I. Carmargo-Mathias, 2006. Morphophysiological differences of the spermathecae of Attini ants (Hymenoptera: Formicidae). Am. J. Agric. Biol. Sci., 1: 58-65. http://www.scipub.org/fulltext/AJAB/AJAB145865.pdf 
Roma, G.C., M.I. Camargo-Mathias and O.C. Bueno, 2006. Faty body cells of gynes and queens in four species of fungus growing ants (Hymenoptera: Formicinae: Attini); relationships with the vitellogenesis. Am. J. Agric. Biol. Sci., 1: 48-57. http://www.scipub.org/fulltext/AJAB/AJAB134857.pdf

Shestakov, L.S., 2008. Studies of vibratory signals in pentatomid bugs (Heteroptera, Asopinae) from European Russia. Entomol. Rev., 88: 20-25. DOI: 10.1007/s11474-008-1003-3

Stefanini, M,C. De Martino and L. Zamboni, 1967. Fixation of ejaculated spermatozoa for electron microscopy. Nature, 216: 173-174. DOI: $10.1038 / 216173 \mathrm{a} 0$

Toft, S., 1995. Value of the aphid Rhopalosiphum padi as food for cereal spiders. J. Applied Ecol., 32: 552-560. http://www.jstor.org/stable/2404652

Wheeler, D., 1996. The role of nourishment in oogenesis. Ann. Rev. Entomol., 41: 407-431. DOI: 10.1146/annurev.en.41.010196.002203

Zanuncio, J.C. and A.S. Fabres, 2001. Species richness and abundance of defoliating Lepidoptera associated with Eucalyptus grandis in Brazil and their response to plant age. Aust. Ecol., 26: 582-589. DOI: 10.1046/j.1442-9993.2001.01126.x

Zanuncio, J.C., T.V. Zanuncio, R.N.C. Guedes and F.S. Ramalho, 2000. Effect of feeding on three Eucalyptus species on the development of Brontocoris tabidus (Het.: Pentatomidae) fed with Tenebrio molitor (Col.: Tenebrionidae). Bioc. Sci. Tech. 10: 443-450. DOI: $10.1080 / 09583150050115025$
Zanuncio, J.C., J.L.D. Saavedra, H.N. Oliveira, D. Degheele and P. De Clercq, 1996. Development of the predatory stinkbug Brontocoris tabidus (Signoret) (Heteroptera: Pentatomidae) on different proportions of an artificial diet and pupae of Tenebrio molitor L. (Coleoptera: Tenebrionidae). Bioc. Sci. Tech., 6: 619-625. DOI: 10.1080/09583159631253

Zanuncio, J.C., W.P. Lemos, M.C. Lacerda, T.V. Zanuncio, J.E. Serrao and E. Bauce, 2006. AgeDependent fecundity and fertility life tables of the predator Brontocoris tabidus (Heteroptera: Pentatomidae) under field conditions. J. Econ. Entomol., 99: 401-407. DOI: 00220493/06/0401Đ0407\$04.00/0

Zanuncio, J.C., M.C. Lacerda, J.S. Zanuncio Jr, T.V. Zanuncio, A.M.C. Silva and M.C. Espindula, 2004. Fertility table and rate of population growth of the predator Supputius cincticeps (Heteroptera: Pentatomidae) on one plant of Eucalyptus cloeziana in the field. Ann. Applied Biol., 144: 357-361. DOI: $10.1111 / \mathrm{j} .1744-$ 7348.2004.tb00351.x 